\title{
Tipe Justifikasi Siswa dalam Menyelesaikan Soal Matematika
}

\author{
Muhammad Ilman Nafi'an \\ Program Studi PGMI, Fakultas Tarbiyah, IAIN Kediri \\ Jl. Sunan Ampel No.7 Ngronggo, Kediri, 64127 \\ Email:ilman@iainkediri.ac.id
}

Article History:

Received: 21-11-2019; Received in Revised: 12-02-2020; Accepted: 28-03-2020

\begin{abstract}
This study aims to describe the Justification Type of Islamic primary school students in Learning There are three cognitive processes that occur in learning mathematics, namely (1) The process of acquiring new information (2) The process of transforming information received (3) Testing the relevance and accuracy of knowledge, The research approach used in this study is qualitative research. This study involved grade 5 Islamic primary school al Bahjah Tulungagung Students as research subjects. The instruments in this study were of two kinds, namely the main instrument and the assistive instrument. The main instrument is the researcher himself, while there are 2 (two) types of assistive instruments, namely: Mathematics Test and interview guidelines. The results of this study are descriptions of each type of justification, at the Assumption (2) Vague / broad statement stage. (3) Rule, (4) Procedural description. (5) Own explanation. In this study, one type of justification was found, namely the experiential connection.
\end{abstract}

Keywords: Justification; Mathematics Problem.

\begin{abstract}
Abstrak
Penelitian ini bertujuan untuk mendeskripsikan Tipe Justifikasi pada siswa SD dalam Pembelajaran Ada tiga proses kognitif yang terjadi dalam belajar, yaitu (1) Proses perolehan informasi baru (2) Proses mentransformasikan informasi yang diterima (3) Menguji relevansi dan ketepatan pengetahuan, Pendekatan penelitian yang digunakan dalam penelitian ini adalah penelitian kualitatif. Penelitian ini melibatkan 5 Siswa SD Islam AI Bahjah Tulungagung sebagai subjek penelitian. Instrumen dalam penelitian ini ada dua macam, yaitu instrumen utama dan instrumen bantu. Instrumen utama adalah peneliti sendiri, sedangkan instrumen bantu ada 2 (dua) macam, yaitu: Tes Matematika dan pedoman wawancara. Hasil dari penelitian ini adalah deskripsi dari masing-masing tipe justifikasi, pada tahap Assumption (2) Vague/broad statement. (3) Rule, (4) Procedural description. (5) Own explanation. Dalam penelitian ini ditemukan satu tipe justifikasi yaitu eksperience connection.
\end{abstract}

Kata Kunci: Justifikasi; Soal Matematika. 


\section{Pendahuluan}

Menurut pendapat As'ari; Devlin-Foltz \& McInvaine; dan Partnership for 21st Century Skills, yang mengharapkan agar pembelajaran mampu mengembangkan kemampuan 4C's (Creativity, Critical Thinking, Communication, Collaboration). berfikir kritis adalah adalah salah satu yang dikembangkan karena memiliki hubungan yang erat dengan penalaran yakni berpikir kritis berkaitan erat dengan dasar-dasar penalaran, pembuktian dan justifikasi. Sehingga kemampuan penalaran, pembuktian, dan justifikasi idealnya menjadi tujuan pembelajaran dalam rangka membentuk kemampuan berpikir kritis siswa. Dalam pengertian yang lebih luas, pembuktian bisa bisa dianggap menjadi pembenaran ${ }^{1}$

Dalam penyelesaian masalah siswa tidak terbiasa melakukan justifikasi. Disisi lain guru sering meminta siswa untuk menjelaskan jawaban siswa ketika melakukan kesalahan dalam menyelesaikan soal matematika ${ }^{2}$. Glass \& Maher menjelaskan tentang perlunya ditekankan tentang pembenaran dalam menyelesaikan masalah ${ }^{3}$. Lebih lanjut Nafi'an menyatakan bahwa dalam proses menyelesaikan masalah matematika siswa melakukan justifikasi dengan memeriksa kembali solusi yang diperoleh, memeriksa prosedur penyelesaian sehingga yakin bahwa solusinya adalah benar ${ }^{4}$. Selain itu guru hanya meminta siswa menjelaskan atau menalar jawaban mereka hanya jika siswa melakukan kesalahan dalam menjawab, sedangkan jawaban yang benar jarang diminta oleh guru untuk diberikan alasan atau penalarannya ${ }^{5}$

Hasil penelitian Back, Mannila dan Wallin menemukan lima tipe justifikasi pada jawaban siswa, yaitu (1) Assumption.: siswa hanya berasumsi dalam memberikan alasan. (2) Vague/broad statement: siswa memberikan alasan yang sangat ringkas dan kurang informatif. (3) Rule: siswa memberikan alasan berdasarkan aturan atau definisi. (4) Procedural description: siswa menjelaskan alasannya secara tahap demi tahap. (5) Own explanation: siswa memberikan alasan menggunakan bahasa mereka sendiri atau menggunakan simbol ${ }^{6}$. Sedangkan penelitian Amorim dkk menyatakan

1 Abdur Rahman As'ari, “Integrasi Budaya, Psikologi, Dan Teknologi Dalam Membangun Pendidikan Karakter Melalui Matematika Dan Pembelajarannya," in Prosiding Seminar Nasional Matematika Dan Pendidikan Matematika, 2018, 152.

2 Ivy Kidron and Tommy Dreyfus, "Justification Enlightenment and Combining Constructions of Knowledge," Educational Studies in Mathematics 74, no. 1 (May 1, 2010): 321, https://doi.org/10.1007/s10649-009-9228-7.

3 Barbara Glass and Carolyn A. Maher, "Students' Problem Solving and Justification.," International Group for the Psychology of Mathematics Education, 2004, 463-70.

${ }^{4}$ Muhammad Ilman Nafi'an, "Bagaimana Kemampuan Siswa Sd Dengan Gaya Kognitif Field Independen Memecahkan Masalah Matematika?," Jurnal Pendidikan Dan Pembelajaran Anak Sekolah Dasar 1, no. 02 (2016).

5 Glass and Maher, "Students' Problem Solving and Justification."

${ }^{6}$ Ralph-Johan Back, Linda Mannila, and Solveig Wallin, "Student Justifications in High School Mathematics," in Proceedings of CERME, vol. 6, 2010, 291-300. 
bahwa siswa tidak cukup menggunakan bukti justifikasi hanya menggunakan buku yang ada, akan tetapi harus secara mandiri melakukan eksperimen, dugaan, bukti secara tepat dan teliti7.

NCTM menjelaskan tentang pentingnya justifikasi dalam pembelajaran matematika ${ }^{8}$. Lebih lanjut dikatakan bahwa siswa perlu memiliki kemampuan justifikasi dengan baik, walapun dalam pembelajaran matematika jarang sekali guru mengetahui tentang kemampuan justifikasi siswa9. Para guru belum sadar bahwa dengan mengetahui kemampuan justifikasi siswa maka akan berdampak pada pengajaran yang mengarah pada pemahaman konsep, kemampuan komunikasi matematis, dan meningkatkan kemampuan berfikir kritis.

Knuth mengatakan bahwa siswa harus menjadikan pembuktian (justifikasi) sebagai alat yang bermakna dalam mempelajari Matematika ${ }^{10}$. Ketika berpikir secara matematis, siswa mesti belajar bagaimana menjustifikasi, menjelaskan alasan mengapa jawaban mereka benar, dan meyakinkan guru serta siswa yang lain, pendapat tersebut diperkuat dengan pendapatnya pengetahuan yang tidak terjustifikasi adalah pengetahuan yang tidak masuk akal, sehingga tentu saja tidak dapat dinalar ${ }^{11}$.

Beberapa hasil penelitian tentang justifikasi antara lain Jane Lo, Grant dan Flowers yang mengaitkan justifikasi dengan pemahaman konsep matematika ${ }^{12}$. Dijelaskan bahwa ketidakmampuan siswa dalam menjelaskan apa yang dipikirkan sering dikaitkan dengan pemahaman siswa yang kurang lengkap terhadap soal yang dihadapi. Sehingga pemahaman siswa terhadap sebuah konsep Matematika yang mendalam diduga mampu meningkatkan kemampuan justifikasi. Begitu pula sebaliknya, kemampuan siswa dalam melakukan justifikasi akan meningkatkan pemahamannya.

7 Marta Élid Amorim, Ruy César Pietropaolo, and Arthur Belford Powell, "Knowledge for Teaching Justifications and Proofs for Future Mathematics Teachers," Acta Scientiae 21, no. 5 (2019): 81-101.

8 National Council of Teachers of Mathematic, "Executive Summary Principles and Standards for School Mathematics," Principles and Standards for School Mathematics (blog), 2004,

https://www.nctm.org/uploadedFiles/Standards_and_Positions/PSSM_ExecutiveSummary.p df.

9 D.L. Ball and Hyman Bass, "Making Mathematics Reasonable in School," A Research Companion to Principles and Standards for School Mathematics, January 1, 2003, 27-44.

10 Knuth, E. J. Secondary School Mathematics Teachers' Conceptions of Proof. Journal for Research in Mathematics Education, 2002, 33.

11 Ball and Bass, "Making Mathematics Reasonable in School."

12 Jane-Jane Lo, Theresa J. Grant, and Judith Flowers, "Challenges in Deepening Prospective Teachers' Understanding of Multiplication Through Justification," Journal of Mathematics Teacher Education 11, no. 1 (2008): 5-22. 
Dreyfus dan Kidron ${ }^{13}$ serta Brodie ${ }^{14}$, yang menjelaskan bahwa seseorang yang melakukan proses justifikasi secara tidak langsung juga sedang membangun pengetahuannya. Ketika siswa memiliki kemampuan justifikasi, mereka sekaligus mampu mengonstruksi pengetahuan yang baru secara mandiri,

Berdasarkan hal tersebut, penelitian ini mencoba mengungkap tipe justifikasi siswa dalam menyelesaikan soal matematika dengan mengembangakn tipe justifikasi yang diperkenalkan oleh Back, Mannila dan Wallin. Data yang diperloeh selanjutnya dianalisis secara kualitatif dengan pendekatan analisis konten.

\section{Metode}

Penelitian ini adalah penelitian kualitatif dengan subjek penelitian siswa kelas 5 SD Islam Al Bahjah Tulungagung yang berjumlah 30 siswa. Pengambilan data dilakukan melalui soal tes matematika yang disajikan dalam bentuk cerita. Siswa diminta untuk memberikan justifikasi (benar dan salah) terhadap pernyataan tersebut beserta alasannya. Dari jawaban siswa diperoleh data tertulis yang bersifat deskriptif tentang tipe justifikasi siswa. Data tersebut kemudian di analisis dengan pendekatan analisis konten ${ }^{15}$. Jawaban siswa dianalisis dan direduksi menjadi beberapa kategori jawaban. Untuk menjamin keabsahan data maka peneliti menggunakan triangulasi metode yaitu mencocokan antara tes tulis dan wawancara16. Dari hasil analisis tersebut justifikasi siswa dikelompokkan dan disajikan dalam bentuk tabel distribusi justifikasi siswa.

\section{Hasil dan Diskusi}

Tes matematika yang digunakan dalam penelitian ini adalah tes matematika yang disajikan dalam soal cerita sebagai berikut:

Mbah Taslim adalah soerang Petani. Setiap musim hujan beliau selalu mencangkul di sawah ditemani 5 orang temanya. Mereka berangkat pagi-pagi dan pulang menjelang siang. Sudah menjadi kebiasaan bahwa setiap selesai mencangkul Mbah Taslim dan 5 orang temanya tidak langsung pulang, melainkan mandi terlebihdahulu di kamar mandi dekat sawah sekaligus menunaikan ibadah sholat dzuhur. Berdasarkan hal tersebut, tentukan

13 Kidron and Dreyfus, "Justification Enlightenment and Combining Constructions of Knowledge."

${ }^{14}$ Karin Brodie, Teaching Mathematical Reasoning in Secondary School Classrooms, vol. 775 (Springer Science \& Business Media, 2009).

15 Mark Mason, "Critical Thinking and Learning," Educational Philosophy and Theory 39, no. 4 (2007): 339-349. 2015).

${ }^{16}$ Lexi J.Moleong, Metodelogi Penelitian Kualitatif (Bandung: PT Remaja Rosdakarya, 
apakah pernyataan di bawah ini benar atau salah. Kemukakan juga alasan dari jawaban tersebut.

1. Bak mandi berbentuk balok

2. Volume air pada bak mandi adalah $1 \mathrm{~m}^{3}$.

3. Masing-masing orang membutuhkan 5 liter air untuk satu kali mandi

4. Air pada bak mandi tidak cukup untuk mandi sebanyak 5 orang

Rekapitulasi justifikasi 30 orang siswa terhadap empat pernyataan tersebut dapat dilihat pada Tabel 1.

Tabel 1. Rekapitulasi Justifikasi siswa

\begin{tabular}{lccc}
\hline \multicolumn{1}{c}{ Pernyataan } & $\begin{array}{c}\text { Benar } \\
\text { (siswa) }\end{array}$ & $\begin{array}{c}\text { Salah } \\
\text { (siswa) }\end{array}$ & $\begin{array}{c}\text { Tidak memberikan } \\
\text { Justifikasi } \\
\text { (siswa) }\end{array}$ \\
\hline Bak mandi berbentuk balok & 14 & 16 & 0 \\
\hline $\begin{array}{l}\text { Volume air pada bak mandi } \\
\text { adalah 1 m }\end{array}$ & 9 & 17 & 4 \\
\hline $\begin{array}{l}\text { Masing-masing orang } \\
\text { membutuhkan 5 liter air } \\
\text { untuk satu kali mandi }\end{array}$ & 2 & 28 & 0 \\
$\begin{array}{l}\text { Air pada bak mandi tidak } \\
\text { cukup untuk mandi } \\
\text { sebanyak 6 orang }\end{array}$ & 15 & 12 & 3 \\
\hline
\end{tabular}

Berdasarkan Tabel 1, selanjutnya dipilih 6 subjek sebagai perwakilan dari masing-masing justifikasi. Demi alasan perlindungan terhadap identitas subjek, maka nama ke-6 subjek tersebut disimbulkan sebagai SA, SV, SR, SP, SO, dan SP. Selanjutnya, alasan-alasan dari justifikasi siswa dikelompokkan dan dianalisis dengan menggunakan pendekatan analisis konten sehingga diperoleh deskripsi dari masing-masing tipe justifikasi. Hasil wawancara terhadap subjek penelitian tersebut secara berurutan diuraikan sebagai berikut.

Hasil wawancara terhadap subjek SA tentang kamar mandi yang berbentuk balok adalah sebagai berikut.

\section{G : "apakah benar kamar mandi berbentuk balok?”}

S : "perkiraan benar, seperti kebanyakan bentuk kamar mandi"

Subjek SA melakukan justifikasi dengan menjawab benar bahwa bak kamar mandi berbentuk balok. Subjek melakukan justifikasi berdasarkan asumsi bahwa seperti kebanyakan bentuk bak kamar mandi yang seperti balok, sehingga subjek masuk kategori tipe Assumption. Hal tersebut sesuai dengan pendapat yang menyatakan bahwa siswa dengan justifikasi 
Assumption dalam memberikan justifikasi selalu memberikan alasannya ${ }^{17}$. Hasil wawancara terhadap subjek SV sebagai berikut.

G : “apakah benar kamar mandi berbentuk balok?”

S : "tidak pasti"

G : "dapatkah mengungkapkan alasanya?"

$\mathrm{S}$ : "tidak dapat"

Subjek SV melakukan justifikasi tetapi tidak menjawab pertanyaan secara jelas, apakah pernyataan tersebut benar atau salah. Subjek hanya menjawab dengan kata "tidak pasti", serta tidak mengungkapkan alasan atas jawaban tersebut. Berdasarkan hal tersebut, tipe justifikasi SV termasuk dalam kategori justifikasi Vague. Hal tersebut sesuai dengan pendapat yang menyatakan bahwa siswa dengan justifikasi Vague memberikan informasi secara singkat dan tidak begitu jelas ${ }^{18}$.

Hasil wawancara terhadap subjek SR sebagai berikut.

G: "apakah benar volume air pada bak mandi adalah $1 \mathrm{~m}^{3}$ ”

S: "benar, tapi lebih tepat $\frac{1}{2} \mathrm{~m}^{3}$ ”

G: "sebutkan alasanya!"

S: "saya belum pernah menemui (bentuk bak mandi) yang kotak (seperti kubus)"

Berdasarkan wawancara tersebut subjek SR melakukan justifikasi dengan meberikan alasan bahwa benar volume bak kamar mandi adalah $1 \mathrm{~m}$ 3 jika setiap panjang sisinya adalah satu meter. Tetapi dalam kebanyakan kamar mandi tidak berbentuk kubus tetapi balok. Jadi volume ideal adalah $\frac{1}{2} m^{3}$ yang di peroleh dari perkalian panjang, lebar dan tinggi. Subjek memberi angka pada masing-masing sisi yaitu panjangnya adalah satu meter, lebarnya 0,5 meter dan tingginya adalah 1 meter. Sehingga jawabanya adalah $\frac{1}{2} m^{3}$, Dari sini, subjek memberikan alasan berdasarkan aturan dan definisi tentang balok. Tipe justifikasi SR termasuk dalam kategori justifikasi rule. Hal tersebut sesuai dengan pendapat yang menyatakan bahwa seseorang dengan justifikasi tipe rule bisa menjelaskan berdasarkan aturan dan definisi yang $\operatorname{ada}^{19}$.

${ }^{17}$ Back, Mannila, and Wallin, "Student Justifications in High School Mathematics."

18 Ibid.

19 Ibid. 
Hasil wawancara terhadap subjek SP sebagai berikut.

G: "Benar atau salah bahwa masing-masing orang membutuhkan 5 liter air untuk satu kali mandi?"

$S$ : "Salah pak, jika $1 \mathrm{dm}^{3}=1$ liter, maka jumlah volume air 1000 liter, jika dibagi enam orang menjadi 166 liter"

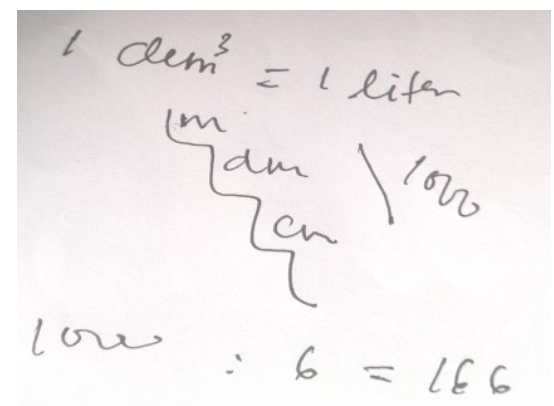

Gambar 1. Hasil Jawaban Subjek SP

Subjek SP melakukan justifikasi dengan menjawab salah jika masingmasing orang membutuhkan 5 liter air untuk satu kali mandi. Kemudian subjek menjelaskan tahapan dari jawaban tersebut, pertama melakukan konversi 1 liter $=1 \mathrm{dm}^{3}$, kemudian tahap ke dua menentukan volume keseluruhan dari bak mandi yaitu $1 \mathrm{~m}^{3}=1000$ liter, tahap ketiga membagi 1000 liter dengan enam orang. 1000:6=166 liter per orang. Jadi satu orang membutuhkan 5 liter air untuk mandi. Berdasarkan jawaban tersebut dapat dikatakan bahwa subjek SP termasuk justifikasi tipe procedural description. Hal tersebut sesuai pendapat yang menyatakan bahwa seseorang dengan justifikasi tipe procedural description menjelaskan sesuatu yang dikerjakan ke dalam langkah-langkah prosedur yang jelas ${ }^{20}$.

Hasil wawancara terhadap subjek SO sebagai berikut.

\section{G : "Benar atau salah bahwa air pada bak mandi tidak cukup untuk mandi sebanyak 6 orang?" \\ $S$ : "Salah, karena ada kran air yang terus mengalir, jadi tetap cukup."}

Berdasarkan wawancara tersebut SO melakukan justifikasi dengan menjawab salah bahwa air pada bak mandi cukup untuk mandi sebanyak 6 orang. Subjek menjelaskan bahwa sisa dari bak kamar mandi bisa terus bertambah karena pada umumnya di atas kamar mandi ada kran air yang selalu di aliri air. Apabila airnya habis digunakan mandi satu orang, maka dengan sendirinya air akan bertambah dan cukup untuk digunakan mandi sebanyak 6 orang. SO memberikan alasan menggunakan bahasa mereka

20 Ibid. 
sendiri sehingga SO masuk ke dalam kategori justifikasi own explanation. Seseorang yang masuk dalam justifikasi own explanation akan menjelaskan sesuatu dengan ide dan gaya bahasanya sendiri ${ }^{21}$.

Hasil wawancara terhadap SE sebagai berikut.

\section{G: "Apakah benar kamar mandi berbentuk balok" \\ S : "Yang saya tahu, kamar mandi di sawah berbentuk tabung, karena terbuat dari tong" \\ G: "Tahu dimana?" \\ S : "Dulu ketika saya disawah dan mandi di kamar mandi (yang dibangun oleh dinas) pertanian"}

Subjek SE melakukan justifikasi dengan menjawab salah, bahwa bak kamar mandi berbentuk balok. Seharusnya bak mandi berbentuk tabung. SE menjawab berdasakan pengalamanya bahwa pernah melihat kamar mandi yang dibangun oleh dinas pertanian di sawah. Siswa juga menyatakan bahwa bentuk kamar mandi di sawah berbeda dengan kamar mandi di rumah yang biasanya berbentuk seperti balok. SE melakukan justifikasi berdasarkan pengalamanya. Justifikasi tersebut tidak ditemukan di tipe justifikasi oleh Back, Mannila dan Wallin sehingga peneliti menamai tipe justifikasi tersebut dengan justifikasi kategori experience connection, yaitu siswa melakukan justifikasi dengan mengaitkan terhadap pengalaman dalam kehidupan sehari-hari.

\section{Kesimpulan}

Penelitian kualitatif ini telah dilaksanakan di SD Islam Al Bahjah Tulungagung. Dari hasil peneltian yang diperoleh dapat disimpulkan bahwa pada tipe Assumption siswa melakukan justifikasi dengan memberikan alasan berdasarkan asumsi. Hal ini tentu kurang produktif dalam belajar matematika, sehingga seyogyanya guru melatih siswa untuk belajar mencari fakta tentang jawaban siswa. Pada justifikasi tipe Vague/broad statement, siswa melakukan justifikasi tetapi jawabanya tidak informative. Pada justifikasi tipe Rule, siswa memberikan justifikasi dengan aturan yang ada. Pada justifikasi tipe Procedural description siswa memberikan justifikasi dengan menjelaskan prosedur tertentu. Pada justifikasi tipe Own explanation siswa memberikan jutifikasi dengan menjelaskan menggunakan bahasa sendiri. Dalam penelitian ini ditemukan satu tipe justifikasi yaitu exsperience connection yaitu siswa melakukan justifikasi berdasarkan pengalaman dalam kehidupan sehari-hari. 


\section{Saran}

Dalam penelitian ini telah ditemukan justifikasi kategori experience connection. Sebuah kategori justifikasi baru dari 5 tipe justifikasi yang sebelumnya dikemukakn oleh Back, Mannila dan Wallin. Penelitian ini masih memungkinkan untuk dikembangkan dengan mengkaji lebih dalam interaksi dan komunikasi yang terjadi antara guru dengan siswa dalam proses justifikasi. Hal ini disebabkan ketika dalam melakukan justifikasi, siswa tidak lepas dari kegiatan komunikasi dan interaksi selama kegiatan pembelajaran.

\section{Daftar Pustaka}

Amorim, Marta Élid, Ruy César Pietropaolo, and Arthur Belford Powell. "Knowledge for Teaching Justifications and Proofs for Future Mathematics Teachers." Acta Scientiae 21, no. 5 (2019): 81-101.

As'ari, Abdur Rahman. "Integrasi Budaya, Psikologi, Dan Teknologi Dalam Membangun Pendidikan Karakter Melalui Matematika Dan Pembelajarannya." In Prosiding Seminar Nasional Matematika Dan Pendidikan Matematika, 2018.

Back, Ralph-Johan, Linda Mannila, and Solveig Wallin. "Student Justifications in High School Mathematics." In Proceedings of CERME, 6:291-300, 2010.

Ball, D.L., and Hyman Bass. "Making Mathematics Reasonable in School." $A$ Research Companion to Principles and Standards for School Mathematics, January 1, 2003, 27-44.

Brodie, Karin. Teaching Mathematical Reasoning in Secondary School Classrooms. Vol. 775. Springer Science \& Business Media, 2009.

Glass, Barbara, and Carolyn A. Maher. "Students' Problem Solving and Justification." International Group for the Psychology of Mathematics Education, 2004, 463-70.

J.Moleong, Lexi. Metodelogi Penelitian Kualitatif. Bandung: PT Remaja Rosdakarya, 2015.

Kidron, Ivy, and Tommy Dreyfus. "Justification Enlightenment and Combining Constructions of Knowledge." Educational Studies in Mathematics 74, no. 1 (May 1, 2010): 75-93. https://doi.org/10.1007/s10649-0099228-7.

Lo, Jane-Jane, Theresa J. Grant, and Judith Flowers. "Challenges in Deepening Prospective Teachers' Understanding of Multiplication Through Justification." Journal of Mathematics Teacher Education 11, no. 1 (2008): 5-22.

Mason, Mark. "Critical Thinking and Learning." Educational Philosophy and Theory39, no. 4 (2007): 339-349.

Nafi'an, Muhammad Ilman. "Bagaimana Kemampuan Siswa Sd Dengan Gaya Kognitif Field Independen Memecahkan Masalah Matematika?" Jurnal Pendidikan Dan Pembelajaran Anak Sekolah Dasar 1, no. 02 (2016). 

Maret-2020, Vol.8, No.1, hal.13-22

National Council of Teachers of Mathematic. "Executive Summary Principles and Standards for School Mathematics." Principles and Standards for School Mathematics (blog), 2004. https://www.nctm.org/uploadedFiles/Standards_and_Positions/PSSM_ ExecutiveSummary.pdf. 